\title{
СТРАТЕГИИ МЕЖДУНАРОДНЫХ ИНСТИТУТОВ В ОТНОШЕНИИ КОСОВО, АБХАЗИИ, ЮЖНОЙ ОСЕТИИ И ПРИДНЕСТРОВЬЯ В 1990-х И 2000-х годах: АНАЛИЗ ДОСТИЖЕНИЙ И ОШИБОК
}

\begin{abstract}
Аннотация: Предмет исследования - роль, которую международные институты - ООН (как носитель международного права), НАТО, позичионирующая себя в качестве гаранта безопасности, и ЕС (как региональный лидер) - сыграли в судьбе таких государственных образований, как Косово, Абхазия, Южная Осетия и Приднестровье. В эпоху глобализации возникает новое пространство и новые рамки действия: политика выходит за пределы государств и грании, вследствие чего появляются дополнительные игроки, новые роли, новые ресурсы, незнакомые правила, новые противоречия и конфликты. Поэтому необходимо действовать в рамках институтов, так как это позволяет увеличивать информированность, сократить трансакционные издержки, а также открывает новые возможности. В основе исследования лежит системный метод, который дает возможность найти корреляции между взаимодействующими элементами и выявить "правила» такого взаимодействия, а также обеспечить интеграцию и систематизацию аналитически полученного материала. Выбор сделан в пользу сравнительного подхода, а именно казусно-ориентированного сравнения, позволяющего подробно рассмотреть специфические черты выше обозначенных случаев. Применяется исторический подход, поскольку это необходимо для адекватного понимания степени участия в этих процессах международных институтов. Кроме того, при анализе строительства политических и правовых в непризнанных/частично признанных государствах был использован институциональный подход, который позволил, с одной стороны, оценить влияние институтов на политический процесс, а с другой - понять специфику их функционирования с учетом влияния неформальных норм и практик. Научная новизна исследования обусловлена тем, что автор на примере Косово, Абхазии, Южной Осетии и Приднестровья попытался дать объективную оценку действий международных организаций в отношении непризнанных государств, а также предложил свои «рецепты» для выработки более рационального подхода к ним на основе фактов изложенных в статье. Ключевые слова: международные институты, провозглашение независимости, стратегия, Косово, Абхазия, Приднестровье, ООН, непризнанные государства, НАTO, ЕС.
\end{abstract}

П роблемное поле данной статьи определяет следующий вопрос: какую роль международные институты - ООН (как носитель международного права), НАТО, позиционирующая себя в качестве гаранта безопасности, и ЕС (как региональный лидер) - сыграли в судьбе таких государств как Косово, Абхазия, Южная Осетия и Приднестровье. Выбор в пользу международных институтов, несмотря на главенствующую роль государств на мировой арене, сделан неслучайно. В эпоху глобализации возникает новое пространство и новые рамки действия: политика выходит за пределы государств и границ, вследствие чего появляются дополнительные игроки, новые роли, новые ресурсы, незнакомые правила, новые противоречия и конфликты ${ }^{1}$. 1 Бек У. Власть и её оппоненты в эпоху глобализма. Новая
всемирно-политическая экономия / Пер. с нем. А.Б. Григо-
Поэтому необходимо действовать в рамках институтов, так как это позволяет увеличивать информированность, сократить трансакционные издержки, а также открывает новое окно возможностей.

Сложно сказать, что до сегодняшнего момента международные институты вели себя адекватно по отношению к de facto государствам: в качестве примеров можно вспомнить как операцию НАТО в 1999 году, так и предоставление ЕС режима наибольшего благоприятствования и массированной экономической помощи Косово одновременно при одновременной экономической блокаде Приднестровья. Эта непоследовательность придает еще большую актуальность поднятой теме: с точки зре-

рьева, В.Д. Седельникова; послесловие В.Г. Федотовой, Н.Н. Федотовой. - М.: Прогресс-Традиция; Издательский дом «Территория будущего», 2007. - С.22. 
ния автора, пришло время прекратить политику «двойных стандартов» и дать объективную оценку проделанной работе.

\section{Роль международных институтов в решении косовского вопроса в 1990-е-2000-е годы}

По данным Статистического Бюро Югославии, на начало 1990 года на территории Косово проживало 1,95 млн. человек, 82\% которых были этническими албанцами, 10\% - этническими сербами, 8\% - членами других этнических групп ${ }^{2}$. Когда Белград стал притеснять албанское население в крае, началось возглавленное И. Руговой пассивное сопротивление сербским властям. Параллельно шло формирование вооруженных подразделений албанских экстремистов (Освободительная Армия Косово ОАК), боровшихся за независимость и моноэтничность края: косовский кризис начал постепенно интернационализироваться.

До 1998 года сербское правительство медлило с использованием военных подразделений против вооруженной группировки албанцев, но в связи с эскалацией конфликта ${ }^{3}$ к этой мере все же пришлось прибегнуть. Необходимо отметить, что полицейская операция, санкционируемая С. Милошевичем проводилась в максимально закрытом режиме, что повлекло за собой волну албанских беженцев и спровоцировало подозрения в этнических чистках.

В связи с этим в сентябре 1998 года СБ ООН издает резолюцию №11994, в которой конфликтующие стороны призываются к прекращению насильственных действий, руководству Югославии предписывается остановить деятельность всех силовых ведомств на территории автономии, а ру-

\footnotetext{
2 International Criminal Tribunal for the former Yugoslavia. Report on the size and ethnic composition of the population of Kosovo [Electronic resource]. - Mode of access: http://www. icty.org/x/file/About/OTP/War_Demographics/en/milosevic_ kosovo_020814.pdf

3 Как отмечает в своей книге американский конфликтолог Джон Бертон, в ткань этнополитического конфликта вплетены различные ценности, а именно традиции, обычаи, иные культурные характеристики, которые принципиальны для любой этнической группы. Следовательно, защита этих ценностей подразумевает проявление агрессивного или оборонительного поведения (Burton J. Conflict and Prevention. Houdmils, Basingstoke, Hampshire and London, 1990).

4 Резолюция 1199(1998), принятая Советом Безопасности на его 3930-м заседании, 23 сентября 1998 года [Электронный ресурс]. - Режим доступа: http://www.un.org/russian/ documen/scresol/res1998/res1199.htm
}

ководству косовских албанцев - осудить террористические акты и другие насильственные действия по отношению к сербскому населению. Миссия по контролю за выполнением данной резолюции была возложена на наблюдателей от ОБСЕ, которые по прошествии полгода предоставили объемный доклад ${ }^{5}$, отражавший военную и гуманитарную стороны конфликта - основная вина за эскалацию вооруженного конфликта возлагалась на Милошевича.

Хотя сам президент СРЮ не разделял точку зрения представителей ОБСЕ, он все же согласился на участие югославской делегации в переговорах с Ибрагимом Руговой. Позднее к этим переговорам присоединились и лидеры ОАК, а США и НАТО выразили намерение оказать посреднические услуги. Таким образом, на переговорном столе оказался документ, разработанный Государственным департаментом США и, предусматривающий ${ }^{6}$ 1) вывод сербских вооруженных сил с территории автономии за исключением 1400 пограничников и 2500 полицейских; 2) разоружение формирований ОАК в течение трех месяцев после подписания соглашения; 3) возвращение административно-политического статуса Косово к ситуации 1989 года без права пересмотра в течение трех лет и 4) ввод в Косово 30-тысячного контингента НАТО, сфера действия которого должна была распространяться на всю Сербию.

В то время как последний пункт соглашения оказался неприемлемым для Сербии как для суверенного государства, албанская делегация, изначально настроенная против соглашения, в итоге согласилась со всеми его условиями. Цена отказа была высокой - в марте 1999 года началась воздушная операция НАТО против СРЮ, получившая название "Allied Forces". Она продолжалась 78 дней и завершилась подписанием 9 июня 1999 года Военно-Технического соглашения между правительствами СРЮ и Республики Сербии и международными силами безопасности (СДК), а также принятием резолюции №1244 Совета Безопасности $\mathrm{OOH}^{7}$. За три месяца бомбардировок авиация НАТO

\footnotetext{
5 OSCE. Human Rights in Kosovo: As seen, As told [Electronic resource]. - Mode of access: http://www.osce.org/kosovo/17781

6 Rambouillet Agreement: Interim Agreement for Peace and Self-Government in Kosovo [Electronic resource]. - Mode of access: http://www.state.gov/www/regions/eur/ksvo_ rambouillet_text.html

Резолюция 1244 (1999), принятая Советом Безопасности на его 4011-м заседании, 10 июня 1999 года [Электронный ресурс]. - Режим доступа: http://www.un.org/russian/ documen/scresol/res1999/res1244.htm
} 
нанесла 2300 воздушных ударов по 995 объектам на территории СРЮ․․ Стране был причинен значительный экономический ущерб, который оценивается более чем в 100 млрд. долларов 9

Стоит отметить, что резолюция Совета Безопасности предусматривала создание в крае временной гражданской администрации - Миссии Организации Объединенных Наций в Косово (МООНК), в обязанности которой входило содействие установлению (до окончательного урегулирования) автономии и самоуправления в Косово, содействие политическому процессу, оказание помощи в восстановлении ключевых объектов инфраструктуры и других хозяйственных объектов. Через два года глава МООНК утвердил «Конституционные рамки временного самоуправления в Косово», но сербская и албанская стороны подвергли их острой критике: сербы посчитали этот документ уступкой албанским экстремистам, а сами албанцы заявили, что он не предоставил более широких полномочий косовскому парламенту ${ }^{10}$.

Что примечательно, принятая Советом Безопасности ООН резолюция подтвердила территориальную целостность СРЮ и установила международный протекторат над Косово, но не привела к разрешению основных проблем - вопросов о статусе края и о положении сербского меньшинства ${ }^{11}$. После установления протектората большая часть сербского населения была вынуждена покинуть территорию Косово или проживать в анклавах, охраняемых миротворцами.

В 2007 году дебаты по будущему статусу Косово вступили в свою решающую фазу: лучшим путем к обеспечению мира и стабильности в регионе посчитали принятие резолюции, основанной непосредственно на плане, предложенном Посланником ООН М. Ахтисаари. Он представлял

\footnotetext{
8 Гуськова Е.Ю. Политика ООН и военные действия НАТО на территории бывшей Югославии в 90-е годы двадцатого века // Балканские страны и международные организации: модели отношений на примере Болгарии, Румынии и Югославии. - М.: ИНИОН, 2000. - С. 51-100.

9 Тягутенко Л.В. Союзная Республика Югославия на рубеже XXI века. Природа югославского кризиса // «Новая и новейшая история» - 2001- № 3 - С. 28-45.

10 Ковач М. Интернационализация конфликта в Косово и пути урегулирования [Электронный ресурс]. - Режим доступа: http://cosmopolis.mgimo.ru/index.php?option=com_ content $\&$ task $=$ view\&id $=158$

11 Юго-Восточная Европа в эпоху кардинальных перемен/ Под ред. А.А. Язьковой. - М.: Издательство «Весь Мир», 2007. - C. 135.
}

собой компромиссное решение, предлагающее косовским албанцам перспективу независимости, косовским сербам - обширные права, безопасность и привилегированные отношения с Сербией. Однако российская сторона отвергла вариант данной резолюции, так как её авторы исходили из независимости края от Сербии. Как заявил тогда постоянный представитель РФ при ООН Виталий Чуркин, «попытки не мытьем, так катаньем провести понятие о независимости Косово без согласия на то Белграда изначально были обречены на провал» ${ }^{12}$.

Тем не менее, в феврале 2008 года парламент Косово все же ратифицировал декларацию о независимости края, но правительство Белграда признало этот акт недействительным и призвало международное сообщество «аннулировать его как противоречащий международному праву» ${ }^{13}$. Россия поддержала позицию сербского руководства, а российские СМИ ясно дали понять, что обретение Косово суверенной государственности не только противоречит правовым нормам, но и невозможно в силу экономической и политической несостоятельности данной территории. Особенно показательной является статья Юлии Петровской в «Независимой газете» под заголовком «Воля народа, танцы и танки»: «К празднику основательно готовились в каждой семье. Многие албанцы украсили дома, включая недостроенные, новыми флагами и надписями «Независимость», а также занялись уборкой окрестных территорий. Некоторые дороги в центре Приштины помыли при помощи резиновых шлангов. На крыше одного из дорогих отелей, принадлежащего, по слухам, премьер-министру Хашиму Тачи, установили мини-копию американской статуи Свободы. Неожиданно выпавший снег весьма кстати прикрыл мусорные свалки, которыми загромождено все Косово» ${ }^{14}$. В целом это ироничное описание отразило позицию России по поводу появления нового государства на мировой политической арене.

Однако представители Брюсселя и Вашингтона тщательно готовили край к независимости. Об этом можно судить, исходя из нескольких об-

\footnotetext{
12 План Ахтисаари провалился [Электронный ресурс]. Режим доступа: http://www.kommersant.ru/doc/783298

13 Совет Федерации: косовский пример способен погрузить мир в хаос [Электронный ресурс]. - Режим доступа: http://www.rg.ru/2008/02/20/sovfed-kosovo-anons.html

14 Петровская Ю. Воля народа, танцы и танки, 18 февраля 2008 года [Электронный ресурс]. - Режим доступа: http:// www.ng.ru/world/2008-02-18/1_rights.html
} 
стоятельств. Во-первых, в их намерения входило решение нескольких задач ${ }^{15}$ : 1) минимизировать практическую реакцию Сербии и Республики Сербской в Боснии и Герцеговины на провозглашение независимости Косово; 2) позаботиться о том, чтобы власть в Белграде оказалась в руках политических сил, поддающихся влиянию Брюсселя и 3) укрепить хрупкую стабильность в Македонии. Во-вторых, в период с 1999 по 2008 годы Евросоюз предоставил краю экономическую помощь в размере 4 млрд. долларов.

Таким образом, отделение Косово происходило максимально бескровным способом: в конституцию нового государства вносились гарантии прав меньшинств, которые должны были приостановить отток сербов из края, в ноябре и декабре 2007 года были парафированы соглашения о стабилизации и ассоциации между странами EC, Cepбией, Боснией и Герцеговиной, а само провозглашение независимости пришлось на период после президентских выборов в Сербии, где «западник» Борис Тадич победил своего соперника - заместителя руководителя националистической Сербской радикальной партии Томислава Николича ${ }^{16}$.

Если смотреть объективно, то на самых первых этапах кризиса правительство Сербии при посредничестве иных незаинтересованных сторон могло выступить с примиренческим жестом по отношению к населению своей провинции. По мнению американского политолога К. Митчелла, чтобы такой жест был правильно понят, нужно несколько основных условий: 1) он должен быть выгодным для оппонента или, по крайней мере, предполагать некий баланс взаимной выгоды; 2) инициатива должна непременно содержать элемент новизны; 3) желательно, чтобы предложенные действия не имели обратного хода; 4) уступки должны исходить от сильной стороны; 5) необходима увязка с последующими шагами в зависимости от реакции противоположной стороны; 6) предложение должно быть позитивным, а не негативным и 7) инициирующая сторона должна понимать, что она идет на добровольный риск и должна быть готова заплатить определенную цену за свой примиренческий шаг. Ни одно из этих условий не было выполнено в полной мере, и неудивительно,

15 Безопасность Европы / Под ред. В.В. Журкина. - М.: Издательство «Весь Мир», 2011. - С. 182.

16 IFES Election Guide: Presidential Elections in Serbia, 2008 [Electronic resource]. - Mode of access: http://www. electionguide.org/election.php?ID=1393 что тогда появились прогнозы о скором отделении Косово от Сербии - у международного сообщества отсутствовало четкое понимание того, как можно на долгий срок развести «по разным углам» сербов и албанцев.

Проведенное Центром научной политической мысли и идеологии (Центр Сулакшина) исследование выявило, что с точки зрения «большой игры» международные институты в результате конфликта в Косово пришли к следующим достижениям и ошибкам:

1. ОOH (стратегия "Ab initio nullum, semper nullum"17): данная организация практически легитимировала военную операцию НАТО на территории бывшей Югославии принятием резолюции №1244 в 1999 году и при помощи этой же резолюции вывела в дальнейшем край из-под юрисдикции Сербии, создав возможность для самоопределения косоваров в 2008 году.

Известно, что еще до этой операции внутри СБ ООН развернулась острая дипломатическая борьба: если члены НАТО (в частности США и Великобритания) настаивали на применении силовых методов для разрешения конфликта, то Россия и Китай выступали за использование дипломатии и однозначно обещали прибегнуть к праву вето. В этом случае руководство США и НАТО приняли неожиданное решение: применить силу против суверенного государства, члена ООН, без санкции Совета Безопасности в случае, если ультиматум западных посредников на переговорах в Рамбуйе не будет принят югославской стороной.

В новых условиях урегулирование конфликтов лишается надежной международно-правовой основы, решения ООН и ОБСЕ утрачивают авторитетность, переговорный процесс приобретает дополнительную жесткость, участники конфликтов получают импульс к гонке вооружений и эскалации напряженности ${ }^{18}$.

2. НАТО (стратегия "Casus a nullo praestantur"19): в принципе, единственным достижением Североатлантического альянса за 1990-е годы было заявление о себе как о «столпе» нового миропорядка, действующего вне правовых рамок. Ведь, начав

\footnotetext{
17 Из ничего ничего и не выйдет (лат.)

18 Кандель П. Косовский кризис и этнополитические конфликты постсоветского пространства (политические и международно-правовые аспекты взаимовлияния) // Косово: международные аспекты кризиса. - М.: Московский Центр Карнеги, 1999. - С.298.

19 За случай никто не несет ответственности (лат.)
} 
военную операцию на территории бывшей Югославии, США и их союзники по Североатлантическому альянсу нарушили не только ст. 39 Устав ООН, дающую Совету Безопасности право определять «существование любой угрозы миру, любого нарушения мира или акта агрессии» ${ }^{20}$, но и Устав НАТО, ст. 5 которого ограничивает военные операции Альянса территорией государств-членов и только в случае вооруженной агрессии против одного из них $^{21}$. Что примечательно, в ст. 7 Вашингтонского Договора указывается, что Устав НАТО «не подлежит толкованию как [...] затрагивающий преимущественно ответственность Совета Безопасности [OOH] за поддержание международного мира и безопасности».

Однако, учитывая, что для реализации военного вмешательства необходимы значительные ресурсы, единое командование, обеспечение коммуникаций, целью была не просто демонстрация силы как таковой, но и попытка «разнять» противоборствующие стороны. Правда, это сработало только на короткий срок, поэтому нецелесообразно считать это достижением. Кроме того, провозглашение Косово своей независимости также нельзя назвать победой членов НАТО. Конечно, Сербия потеряла часть своей территории, но весьма проблематично заявить, что от этого она стала слабее, ибо Косово никогда не отличалось успешным экономическим развитием.

Край, будучи дотационным еще в социалистической Югославии, таковым и остался. Экспорт равняется 3\% от импорта, а таможенные пошлины составляют 70\% доходов бюджета. Оценка безработицы варьируются от 45 до 60\% и более, причем основная доля работающих занята в обслуживании международных миссий и в формирующихся государственных институтах. Хотя 60\% населения проживает на селе, сельскохозяйственное производство, несмотря на плодородные земли и благоприятный климат, является в основном натуральным. Лишь $10 \%$ сельских хозяйств можно отнести к категории товарных производителей, а 15-20\% - могут квалифицироваться как полукоммерческие 22 . Не стоит рассчитывать также и на приток внешних инвестиций в государство, так как потен-

20 Устав ООН [Электронный ресурс]. - Режим доступа: http://www.un.org/ru/documents/charter/chapter7.shtml

21 Устав НАТО [Электронный ресурс]. - Режим доступа: http://www.nato.int/docu/other/ru/treaty.htm

22 Основные тенденции развития экономики Косово // БИКИ, 18.01.2005. - С.16. циальных инвесторов вряд ли привлечет сложившаяся репутация Косово как европейского центра торговли нелегальными товарами и услугами.

3. EC (стратегия "Culpa in inspiciendo"23): на протяжении почти двух десятилетий Европейский союз придерживался позиции Североатлантического альянса касательно Косово и свое видение, как урегулировать ситуацию в крае, не представлял. После провозглашения независимости Косово, EC взял на себя обязательство помогать новому государству в области правосудия, таможенного и пограничного контроля. Для этих целей была учреждена гражданско-полицейская миссия EULEX в составе 2000 человек. Исходя из решений ЕС, можно судить о том, что организация взяла скорее курс на интеграцию Косово в европейские структуры, чтобы избежать возможных конфликтов между албанским и сербским населением.

\section{Роль международных институтов в решении постсоветского вопроса в 1990-е-2000-е годы}

Абхазия. 17 марта 1991 почти половина населения абхазской республики (по данным Центральной комиссии референдума СССР - 52,3\%) высказалось за сохранение Советского Союза, чем вызвали недовольство властей Грузии, пригрозившей роспуском Верховного Совета Абхазии. Затем на территории Абхазии и Западной Грузии все чаще и чаще стали происходить вооруженные столкновения между абхазами и мегрелами. Кроме того, абхазы сумели заручиться поддержкой чеченских сепаратистов, при этом, сохраняя «теплые отношения» с Москвой, которая постепенно начала «отдаляться» от Закавказья в силу своих экономических и политических проблем.

Ситуация начала еще больше обостряться после того, как в феврале 1992 года в Грузии было восстановлено действие конституции 1921 года, не предусматривавшей гарантии автономии для Абхазии. В ответ на это, в июле 1992 года постановлением Верховного Совета Абхазии было восстановлено действие конституции 1925 года, в которой она признавалась суверенной республикой, строящей отношения с Грузией на договорной основе. Однако в августе того же года переговорный процесс был окончательно прерван неожиданным вступлением грузинских войск в Абхазию.

Вооруженный конфликт продолжался с 1992 по 1993 годы, и, по обнародованным данным сто-

23 Вина в недосмотре (лат.) 
рон, унес жизни 4 тыс. грузин и 4 тыс. абхазов. Потери экономики автономии составили 10,7 млрд. долларов, около 250 тыс. грузин были вынуждены бежать из Абхазии. В 1994 году в Москве между грузинской и абхазской при посредничестве России было подписано соглашение о прекращении огня и разъединении сил ${ }^{24}:$ оно предусматривало участие российских войск в проведении операции СНГ «по поддержанию мира в зоне конфликта Абхазия - Грузия». Одновременно СБ ООН учредил миссию ООН по наблюдению в Грузии ${ }^{25}$. Как указывают эксперты, коллективные миротворческие силы, полностью укомплектованные российскими военнослужащими, контролировали 30-километровую зону безопасности в зоне грузино-абхазского конфликта.

Южная Осетия. В конце 1989 года областной Совет народных депутатов Юго-Осетинской автономной области принял решение о повышение её статуса - до уровня автономной области, но Верховный Совет Грузии не поприветствовал данный шаг. В сентябре следующего года было принято решение об объявлении Юго-Осетинской Советской Демократической Республики и подана заявка на вхождение в состав СССР на правах союзной республики.

В ответ на такую акцию Москва перебросила войска в район конфликта, чтобы избежать кровопролития, но уже в 1992 году Южная Осетия вновь высказалась за присоединение к России, что повлекло за собой решение Грузии подавить сепаратистские настроения. Резко стало возрастать число жертв среди местного населения, и 22 июня 1992 года состоялась важная встреча глав Грузии, России, а также представителей Южной и Северной Осетии.

Спустя два дня были заключено так называемое «Дагомысское соглашение» ${ }^{26}$, предусматривавшее учреждение Смешанной Контрольной Комиссии вовлеченных в конфликт сторон и создание при ней Смешанных сил по установлению мира и поддержанию правопорядка. В июле 1992 года в

\footnotetext{
24 Соглашение о прекращении огня и разъединении сил (Москва, 14 мая 1994 года) [Электронный ресурс]. - Режим доступа: http://www.peacekeeper.ru/ru/?module=pages\&action $=$ view\&id $=92$

25 ООН. Грузия - МООНГ [Электронный ресурс]. - Режим доступа: http://www.un.org/russian/documen/scresol/res1994/ res937.htm

26 Соглашение “О принципах урегулирования грузино-осетинского конфликта” [Электронный ресурс]. - Режим доступа: http://caucasica.org/docs/detail.php?ID=1329
}

Южной Осетии началась миротворческая операция, и в зону конфликта были введены российский, грузинский и осетинский миротворческие батальоны. Вооруженные столкновения были остановлены, но Грузия лишилась контроля над большей частью Южной Осетии.

Приднестровье. Началом конфликта между Кишиневом и Тирасполем являлась разработка в начале 1989 года Верховным Советом (ВС) МССР законопроектов «О государственном языке» и «0 функционировании языков на территории МССР» ${ }^{27}$. В качестве единственного государственного языка признавался не молдавский, а румынский. В то же самое время, русскому языку была отведена лишь роль языка межнационального общения.

Весьма болезненно такого рода изменения были восприняты в наиболее развитом (в промышленном отношении) по сравнению с остальной Молдавией регионе - Приднестровье, большинство жителей которого в силу исторических причин было русскоязычным. Представленные в ВС МССР приднестровские депутаты выступили с инициативой введения двух государственных языков, сохранения кириллической графики и проведения обязательного референдума по упомянутым законопроектам, но оно было отвергнуто националистически настроенным большинством. По городам региона прокатились массовые протесты.

Дальше события развивались стремительно: румынский флаг был объявлен государственным флагом республики, а её название изменено на ССР Молдова (ССРМ); в июне 1990 года ВС ССРМ принял декларацию о суверенитете, что ознаменовало собой начало процесса выхода из состава СССР. Приднестровье также не осталось в стороне и стало активно продвигать идею о создании своего независимого государства. Кроме того, началась автономизация и другого района Молдовы - Гагаузии, куда были введены спецподразделения МВД СССР с целью предотвратить возможные столкновения.

В ноябре 1990 года в приднестровском городе Дубоссары молдавская милиция с применением огнестрельного оружия разогнала митинг протеста против ввода в город сил молдавского МВД: в ходе операции трое приднестровцев было убито, шестнадцать - ранены. В августе 1991 года в Кишиневе принимается декларация о независимости Республики Молдова (РМ), и в ответ на это ВС При-

27 Закон Молдавской ССР «О функционировании языков на территории Молдавской ССР [Электронный ресурс]. - Режим доступа: http://www.medialaw.ru/exussrlaw/l/md/lang.htm 
днестровья провозглашает Приднестровскую Молдавскую Республику. Кишинев принял решение урегулировать подобную «самодеятельность» силовым путем: очаговые столкновения в марте 1992 года к лету того же года переросли в крупномасштабный вооруженный конфликт на берегах Днестра.

Однако в июле 1992 года в Москве между президентами России и Молдавии в присутствии руководителя Приднестровья было подписано Соглашение о принципах мирного урегулирования вооруженного конфликта в Приднестровском регионе Республики Молдова. Через пять лет между представителями Республики Молдова и Приднестровской Молдавской Республикой был подписан Меморандум об основах нормализации отношений: стороны, наконец, согласились строить отношения в рамках общего государства в границах Молдавской ССР на январь 1990 года.

Исходя из выше сказанного, можно сделать вывод о том, что к середине 1990-х годов описанные конфликты были постепенно «заморожены», но при этом им не было придано особое мировое значение, как это было в случае с Косово. В то время как ООН пыталась выполнять свои функции в сфере поддержания мира посредством направления миротворческого контингента в проблемные регионы, НАТО и ЕС вели себя более сдержанно иными словами, заняли выжидательную позицию.

В начале 2000-х годов наметился новый этап в эволюции неурегулированных конфликтов, связанный с попытками тех или иных заинтересованных сторон «разморозить»их и добиться выгодного для себя решения ${ }^{28}:$ к примеру, приход к власти в Молдавии Партии коммунистов во главе с Владимиром Ворониным, «революция роз» в Грузии и избрание президентом Михаила Саакашвили (2003-2004) ознаменовали курс на «реконкисту» - возвращение потерянных ранее территорией и недопущение приобретения ими международного статуса. При этом оба лидера ориентировались, в первую очередь, на западных партнеров, а не на своего ближайшего соседа - Россию. Это было обусловлено тем, что она вела себя весьма непоследовательно: с одной стороны, в 1999 году на Стамбульском саммите ОБСЕ Россия приняла на себя обязательства о выводе воинского контингента с территорий Молдавии и Грузии, а в 2005 году она

28 Смирнов П. «Мерцающий режим» конфликтов самоопределения в Восточной Европе [Электронный ресурс]. - Режим доступа: http://www.intertrends.ru/eleventh/002.htm (дата обращения: 01.06.2011) вынуждена была пойти на договоренность с Грузии о выводе баз из Батуми и Ахалкалаки. С другой стороны, Россия укрепляла «веру в себя» на территории самопровозглашенных государств при помощи предоставления их жителям российского гражданства.

События августа 2008 года (так называемая «пятидневная война») качественно изменили ситуацию в Закавказье. Позиции Южной Осетии и Абхазии значительно укрепились: они видели себя не республиками в составе Грузии, а субъектами международных отношений. Подход России к Грузии приобрел более жесткий характер, потому что её агрессия против Южной Осетии была прямым нарушением норм международного права.

Как указывает Александр Чечевишников, слабая Грузия оказалась формально одним из самых милитаризованных государств, если исходить из соотношения военных расходов и государственного бюджета ${ }^{29}$. Принимая это во внимание, Российская Федерация в августе 2008 года признала Абхазию и Южную Осетию в качестве независимых государств.

Эта акция вызвала волну негодования даже среди тех членов ЕС, которые неформально считались союзниками России. К примеру, канцлер Германии Ангела Меркель назвала такой шаг Москвы «абсолютно неприемлемым». Глава МИД Италии заявил, что такое признание противоречит международному праву, а США посчитали данное событие весьма «прискорбным». В то же самое время глава Молдовы В. Воронин при встрече с президентом РФ Дмитрием Медведевым убеждал российские власти не делать аналогичного шага в отношении Приднестровья. Этого не произошло, поскольку признание независимости удаленного эксклава, возможность реальной поддержки которого в полной мере зависит от характера весьма непростых отношений с Украиной, представляло для Москвы сомнительную ценность.

Тем не менее, на настоящий момент Россия не может похвастаться продуманной стратегией в отношении Абхазии и Южной Осетии. Можно согласиться с тем, что шаг, предпринятый РФ в августе 2008 года, носил вынужденный характер, но является ли он правильным? Признавая независимость Абхазии и Южной Осетии, Россия в своих заявлениях говорила, что хотела оградить, прежде всего,

29 Чечевишников А. Казус Косово и перспективы Закавказья [Электронный ресурс]. - Режим доступа: http://www. intertrends.ru/fourteen/011.htm 
своих граждан и народы республик от агрессии Грузии. Затем она начала налаживать экономические и политические отношения с новыми государствами, но могут ли они стать не реципиентами, а партнерами России ввиду малого количества ресурсов и слабо развитой инфраструктуры?

Известно, что благодаря договору, подписанному с Россией, например, абхазские власти решают, по крайней мере, две задачи $\left.{ }^{30}: 1\right)$ обеспечивают свою безопасность и 2) создают базис для экономического развития. Задачи носят взаимосвязанный характер - только безопасность сможет привлечь инвестиции, без которых обнищавшая за годы войны и блокады Абхазия встать на ноги не сможет. То же самое можно сказать и о Южной Осетии, состояние которой тоже оценивается как «весьма неудовлетворительное». В любом случае, политический выигрыш или проигрыш России от признания двух республик будет виден в ближайшем будущем, и именно он станет свидетельством дальновидности или близорукости её политики.

После проведения анализа «косовского вопроса», был сделан вывод, что основную роль в нем сыграли Североатлантический альянс во главе с США и Европейский Союз, при этом значение $\mathrm{OOH}$ было весьма символично. В принципе на постсоветском пространстве наблюдается практически та же самая ситуация, если не считать, что действия рассматриваемых международных институтов отличаются большей последовательностью и обдуманностью.

1. НАТО (стратегия "Actus purus"31): необходимо отметить, что Североатлантический альянс начал активно включаться в политический процесс на постсоветском пространстве в 2000-е годы. Особенно ярко это было видно на примере государств Закавказья: так, Главком Объединенными Вооруженными Силами НАТО в Европе американский генерал Джеймс Джонс на слушаниях в сенате в марте 2005 года откровенно говорил о том, что Кавказ «в возрастающей степени» важен для интересов США. Пентагон считает Кавказ «ключевой географической точкой в процессе распространения демократии и рыночной экономики в страны Центральной и Юго-Западной Азии».

Отметив важную роль «передового базирования» вооруженных сил США в различных регионах

30 Симонян Ю, Наумов И. Абхазия безофшорная, зато рублевая [Электронный ресурс]. - Режим доступа: http://www. ng.ru/cis/2008-10-07/1_abhazia.html

31 Чистое действие (лат.) мира, генерал заявил: «В дополнение к сохранению наших традиционных линий коммуникаций и доступа, мы ищем доступ к новым объектам и свободе транзита к Черному морю, Кавказу, Ближнему Востоку и Африке для продвижения американских национальных интересов» ${ }^{32}$. Кроме того, по словам генерала, Кавказ является идеальным воздушным коридором между европейскими базами США и их афганской группировкой. Из этих слов вытекает вполне логичный вывод: этот коридор будет использоваться в любой операции - гуманитарной, военной и других, которую США и их вооруженные силы будут проводить на Ближнем Востоке.

Особое место в стратегических планах НАTO занимает Грузия, что доказывают объемы военной помощи, предоставляемые этому государству еще несколько лет назад: в представленном 6 февраля 2006 года Конгрессу США проекте бюджета 2007 финансового года объемы военной помощи составили $^{33}:$ 1) Грузии - \$10 млн. и 1,235 млн. по программе международного военного образования и стажировки; 2) Азербайджану - \$4,5 млн. и \$885 тыс.; 3) Армении - \$3,5 млн. и $\$ 790$ тыс. Более того, президент Грузии Михаил Саакашвили еще в 2006 году заявил, что в 2009 году его государство будет полноправным членом НАТО, и тогда «границу страны будут защищать не грузинские самолеты, вертолеты и танки, а десятки западных самолетов. Наши бывшие братья уже не смогут безнаказанно пересечь нашу границу» ${ }^{34}$.

В ситуацию с Приднестровьем НАТО практически не вмешивается, но стоит отметить, что еще в 2005 году лидеры данного государства в силу неблагоприятной внешнеполитической конъюнктуры согласились на привлечение США к переговорам по данному вопросу. Согласие подключиться к переговорному процессу означает, что западные государства в целом заинтересованы в разрешении кризисных ситуаций, а не в их замораживании.

Нельзя сказать, что стратегия НАТО на постсоветском пространстве, условно обозначенная как «чистое действие», привела к каким-либо весомым достижениям. Североатлантический альянс (как и

\footnotetext{
32 Генерал Джонс: Кавказ исключительно важен для интересов США [Электронный источник]. - Режим доступа: http://www.rian.ru/world/america/20050302/39475539.html

33 Гусейнов В., Денисов А., Савкин Н., Демиденко С. Большой Ближний Восток: стимулы и предварительные итоги демократизации. - М.: ОЛМА Медиа Групп, 2007. - С. 363.

34 Михаил в поход собрался [Электронный ресурс]. - Режим доступа: http://www.rg.ru/2006/02/16/gruzia.html
} 
в случае с Косово) практически не приобрел ничего, что можно обозначить как политический выигрыш. США, будучи партнером Грузии, смогли защитить её интересы, играя на желании грузинской стороны вступить в НАТО, но «выдавить» Россию из Закавказья они не сумели, хотя во время пятидневного конфликта Грузии и Южной Осетии была проведена масштабная информационная война с целью формирования негативного имиджа России в глазах мировой общественности. В итоге Россия, возможно, понесла репутационные издержки, но укрепила авторитет в регионе.

2. ЕС (стратегия "Benevolentiae captande causa" ${ }^{35}$ ): Европейский союз в целом поддерживает политический курс НАТО, но при этом пытается показать, что у него есть свой собственный подход к de facto государствам: это видно хорошо на примере взаимоотношений Молдавии и Приднестровья. Как известно, эффективным инструментов воздействия на кишиневские власти стала Европейская политика соседства, в рамках которой, а также на основе Плана действий ЕС для Молдавии в декабре 2006 года было принято решение о выделении ей в течение трех лет 1,2 млрд. евро на финансирование внутренних реформ, что эквивалентно национальному бюджету страны за последние два года ${ }^{36}$.

Иными словами, ЕС пускает в ход «мягкую мощь» (soft power) и ничего от этого не теряет: в случае Косово была выбрана модель интегрирования проблемного региона, то есть вписывание его в макрорегиональные структуры, в случае Приднестровья - «гарантирование специального автономного статуса в составе молдавского государства» ${ }^{37}$, а в ситуации с Абхазией и Южной Осетией - политика невмешательства и вместе с тем критика России.

С этой точки зрения, политику «двойных стандартов» ЕС можно понять: данный международный институт долгое время развивался в тени США и НАТО, поэтому он не обладает развитыми структурами, поддерживающими безопасность. Европейцам легче договариваться со своими пар-

35 Для снискания благоволения (лат.)

36 Селиванова И.Ф. Восточное направление политики соседства ЕС // Россия и современный мир. - 2008. - № 2. C.106.

37 Приднестровское урегулирование: «В Молдавии опасаются, что Москва заявит о признании независимости Приднестровья» [Электронный ресурс]. - Режим доступа: http:// www.regnum.ru/news/1072168.html тнерами, убеждать их в своей правоте, используя экономические и политические инструменты. В связи с этим, Европейский союз выглядит гораздо привлекательнее в качестве партнера - это можно считать значительным достижением.

3. OOH (стратегия "Custos morum ${ }^{38 ”}$ ): в принципе стратегия ООН в отношении непризнанных государств никак не изменилась, и этот факт осложняет восприятие данного международного института как органа, призванного выполнять функции глобального характера. События в Южной Осетии, Абхазии и Приднестровье (как и в случае с Косово) еще раз показали то, что ООН своей неэффективностью вынуждает и даже поощряет другие региональные организации брать на себя её полномочия. Поэтому о достижениях здесь говорить не стоит.

\section{Итоги}

Во-первых, когда международные институты пытались взаимодействовать с Косово, Южной Осетией, Абхазией и Приднестровьем, они действовали без учета сложности их исторического развития. В связи с этим в случае с Косово они пошли на самый легкий шаг, то есть допустили его отделение от «материнского» государства для достижения элементарной стабильности, а в случае с Южной Осетией, Абхазией и Приднестровьем, не найдя эффективных способов разрешения конфликтов, предпочли их «заморозить». Это нельзя назвать прорывом, так как были созданы опасные прецеденты, которые в дальнейшем могут быть широко использованы для оправдания новых случаев сецессии.

Во-вторых, на протяжении 1990-х и 2000-х годов международные организации использовали разные стратегии в отношении de facto государств.

На территории Югославии Североатлантический альянс руководствовался принципами “Casus a nullo praestantur": Косово для международного института было своего рода показателем не только способности разрешить этнополитический конфликт на Балканском полуострове, «пороховой бочке Европы», но и изъявить притязания на лидирующие позиции в новом мироустройстве после окончания холодной войны. Так как это был первый опыт подобного рода вмешательства во внутренние дела суверенного государства (Сербии), то руководство НАТО действовало импульсивно и

38 Блюститель нравственности (лат.) 


\section{Международные отношения / International Relations / № 1 / 2015}

недальновидно. Однако затем оно стало постепенно готовить край к независимости, делая при этом заявления, что жители без посторонней помощи осознали необходимость приобретения собственной государственности. Вследствие этого, по мнению НАТО, действительно за данный случай никто ответственности не несет. В то же самое время к постсоветским конфликтам был применен более продуманный подход “Actus purus”, выражавшийся, например, в стремлении заполучить доступ к Кавказу посредством военной поддержки Грузии или же участии в переговорном процессе по вопросу статуса Приднестровья.

Стратегию Европейского союза в отношении Косово можно условно назвать "Culpa in inspiciendo" его членам можно вменять в вину то, что они, занимаясь в течение 1990-х годов процессами интеграции, следовали установке Североатлантического альянса при преодолении косовского кризиса и не вносили свой собственный вклад в это дело. Поэтому после признания независимости края они были вынуждены взять курс на его интеграцию в региональные структуры для обеспечения своей же безопасности. Что касается ситуаций с Абхазией, Южной Осетией и Приднестровьем, то здесь ЕС вновь действует в фарватере НАТО (стратегия “ Benevolentiae captande causa”, «для снискания благоволения), но при этом он стремится быть более самостоятельным (в частности, в решении проблемы Приднестровья) во внесении предложений и использовании своей "soft power".

$\mathrm{OOH}$ действовала по принципам "Ab initio nullum, simper nullum" и “Custos morum". Дело в том, что стратегии первых двух международных организаций хоть и отличались близорукостью в некоторых случаях, но все-таки носили более последовательный характер, чем подходы ООН. Более того, совершив многие ошибки в 1990-е годы при решении косовского вопроса, Североатлантический альянс и Европейский союз сумели скорректировать свой политический курс в рамках постсоветского пространства. ООН продолжала использовать традиционные методы и не предлагала никаких новых подходов для взаимодействия с de facto государствами, поэтому её роль на протяжении этих лет носила только формальный характер.

\section{Библиография:}

1. Бек У. Власть и её оппоненты в эпоху глобализма. Новая всемирно-политическая экономия / Пер. с нем. А.Б. Григорьева, В.Д. Седельникова; послесловие В.Г. Федотовой, Н.Н. Федотовой. - М.: Прогресс-Традиция; Издательский дом «Территория будущего», 2007.

2. International Criminal Tribunal for the former Yugoslavia. Report on the size and ethnic composition of the population of Kosovo [Electronic resource]. - Mode of access: http://www.icty.org/x/file/About/OTP/War_Demographics/en/ milosevic_kosovo_020814.pdf

3. Rambouillet Agreement: Interim Agreement for Peace and Self-Government in Kosovo [Electronic resource]. - Mode of access: http://www.state.gov/www/regions/eur/ksvo_rambouillet_text.html

4. Резолюция 1244 (1999), принятая Советом Безопасности на его 4011-м заседании, 10 июня 1999 года [Электронный ресурс]. - Режим доступа: http://www.un.org/russian/documen/scresol/res1999/res1244.htm

5. Гуськова Е.Ю. Политика ООН и военные действия НАТО на территории бывшей Югославии в 90-е годы двадцатого века // Балканские страны и международные организации: модели отношений на примере Болгарии, Румынии и Югославии. - М.: ИНИОН, 2000.

6. Тягутенко Л.В. Союзная Республика Югославия на рубеже XXI века. Природа югославского кризиса // «Новая и новейшая история»-2001-№ 3

7. Ковач М. Интернационализация конфликта в Косово и пути урегулирования [Электронный ресурс].-Режим доступа: http://cosmopolis.mgimo.ru/index.php?option=com_content\&task=view\&id=158 Юго-Восточная Европа в эпоху кардинальных перемен/ Под ред. А.А. Язьковой. - М.: Издательство «Весь Мир», 2007.

8. Безопасность Европы / Под ред. В.В. Журкина. - М.: Издательство «Весь Мир», 2011.

9. Кандель П. Косовский кризис и этнополитические конфликты постсоветского пространства (политические и международно-правовые аспекты взаимовлияния) // Косово: международные аспекты кризиса. - М.: Московский Центр Карнеги, 1999

10. Смирнов П. «Мерцающий режим» конфликтов самоопределения в Восточной Европе [Электронный ресурс]. Режим доступа: http://www.intertrends.ru/eleventh/002.htm (дата обращения: 01.06.2011)

11. Чечевишников А. Казус Косово и перспективы Закавказья [Электронный ресурс]. - Режим доступа: http://www. intertrends.ru/fourteen/011.htm

12. Симонян Ю, Наумов И. Абхазия безофшорная, зато рублевая [Электронный ресурс]. - Режим доступа: http:// www.ng.ru/cis/2008-10-07/1_abhazia.html

13. Гусейнов В., Денисов А., Савкин Н., Демиденко С. Большой Ближний Восток: стимулы и предварительные итоги демократизации. - М.: ОЛМА Медиа Групп, 2007.

14. Селиванова И.Ф. Восточное направление политики соседства ЕС // Россия и современный мир. - $2008 .-$ № 2. 


\section{Мировая политика / World Politics}

15. Приднестровское урегулирование: «В Молдавии опасаются, что Москва заявит о признании независимости Приднестровья» [Электронный ресурс]. - Режим доступа: http://www.regnum.ru/news/1072168.html Блюститель нравственности (лат.)

16. Манойло А.В. Стратегии «управляемого хаоса» в условиях хаотизации международных отношений: миф или реальность? // NB: Международные отношения.-2014.-1.-C. 1-3. DOI: 10.7256/2306-4226.2014.1.10750. URL: http:// www.e-notabene.ru/wi/article_10750.html

17. Семячкин А.А. Российско-индийская концепция стратегического партнерства // Международные отношения.2013.-2.-C. 118-122. DOI: 10.7256/2305-560Х.2013.02.2.

18. И. В. Сурма, В. И. Аникин Современная Россия: методологические аспекты стратегии политического и экономического развития // Национальная безопасность / nota bene.-2012.-3.-C. 4-16.

19. Смирнов А.М. Россия и НАТО в системе европейской безопасности // Национальная безопасность / nota bene.2013.-5.-C. 12-25. DOI: 10.7256/2073-8560.2013.5.9748.

20. Сулакшин С.С. Человек и государство: развитие и управление. Сборник трудов. Т. 1 - М.: Научный эксперт, $2013 .-600$ с.

21. Алейников А.В. Системные конфликты в России: концептуальные основания анализа. Статья 1. // NB: Проблемы общества и политики. - 2013. - 7. - C. 94 - 140. DOI: 10.7256/2306-0158.2013.7.2306. URL: http://www.e-notabene. $\mathrm{ru} / \mathrm{pr} /$ article_2306.html

\section{References (transliterated):}

1. Bek U. Vlast' i ee opponenty v epokhu globalizma. Novaya vsemirno-politicheskaya ekonomiya / Per. s nem. A.B. Grigor'eva, V.D. Sedel'nikova; posleslovie V.G. Fedotovoi, N.N. Fedotovoi. - M.: Progress-Traditsiya; Izdatel'skii dom «Territoriya budushchego», 2007.

2. International Criminal Tribunal for the former Yugoslavia. Report on the size and ethnic composition of the population of Kosovo [Electronic resource]. - Mode of access: http://www.icty.org/x/file/About/OTP/War_Demographics/en/ milosevic_kosovo_020814.pdf

3. Rambouillet Agreement: Interim Agreement for Peace and Self-Government in Kosovo [Electronic resource]. - Mode of access: http://www.state.gov/www/regions/eur/ksvo_rambouillet_text.html

4. Rezolyutsiya 1244 (1999), prinyataya Sovetom Bezopasnosti na ego 4011-m zasedanii, 10 iyunya 1999 goda [Elektronnyi resurs]. - Rezhim dostupa: http://www.un.org/russian/documen/scresol/res1999/res1244.htm

5. Gus'kova E.Yu. Politika OON i voennye deistviya NATO na territorii byvshei Yugoslavii v 90 -e gody dvadtsatogo veka // Balkanskie strany i mezhdunarodnye organizatsii: modeli otnoshenii na primere Bolgarii, Rumynii i Yugoslavii. - M.: INION, 2000.

6. Tyagutenko L.V. Soyuznaya Respublika Yugoslaviya na rubezhe XXI veka. Priroda yugoslavskogo krizisa // «Novaya i noveishaya istoriya»-2001-№ 3

7. Kovach M. Internatsionalizatsiya konflikta $v$ Kosovo i puti uregulirovaniya [Elektronnyi resurs].-Rezhim dostupa: http://cosmopolis.mgimo.ru/index.php?option=com_content\&task=view\&id=158 Yugo-Vostochnaya Evropa v epokhu kardinal'nykh peremen/ Pod red. A.A. Yaz'kovoi. - M.: Izdatel'stvo «Ves' Mir», 2007.

8. Bezopasnost' Evropy / Pod red. V.V. Zhurkina. - M.: Izdatel'stvo «Ves' Mir», 2011.

9. Kandel' P. Kosovskii krizis i etnopoliticheskie konflikty postsovetskogo prostranstva (politicheskie i mezhdunarodnopravovye aspekty vzaimovliyaniya) // Kosovo: mezhdunarodnye aspekty krizisa. - M.: Moskovskii Tsentr Karnegi, 1999

10. Smirnov P. «Mertsayushchii rezhim» konfliktov samoopredeleniya v Vostochnoi Evrope [Elektronnyi resurs]. - Rezhim dostupa: http://www.intertrends.ru/eleventh/002.htm (data obrashcheniya: 01.06.2011)

11. Chechevishnikov A. Kazus Kosovo i perspektivy Zakavkaz'ya [Elektronnyi resurs]. - Rezhim dostupa: http://www. intertrends.ru/fourteen/011.htm

12. Simonyan Yu, Naumov I. Abkhaziya bezofshornaya, zato rublevaya [Elektronnyi resurs]. - Rezhim dostupa: http://www. ng.ru/cis/2008-10-07/1_abhazia.html

13. Guseinov V., Denisov A., Savkin N., Demidenko S. Bol'shoi Blizhnii Vostok: stimuly i predvaritel'nye itogi demokratizatsii. - M.: OLMA Media Grupp, 2007.

14. Selivanova I.F. Vostochnoe napravlenie politiki sosedstva ES // Rossiya i sovremennyi mir. - 2008.-№ 2.

15. Pridnestrovskoe uregulirovanie: «V Moldavii opasayutsya, chto Moskva zayavit o priznanii nezavisimosti Pridnestrov’ya» [Elektronnyi resurs]. - Rezhim dostupa: http://www.regnum.ru/news/1072168.html Blyustitel' nravstvennosti (lat.)

16. Manoilo A.V. Strategii «upravlyaemogo khaosa» v usloviyakh khaotizatsii mezhdunarodnykh otnoshenii: mif ili real'nost'? // NB: Mezhdunarodnye otnosheniya.-2014.-1.-C. 1-3. DOI: 10.7256/2306-4226.2014.1.10750. URL: http://www.enotabene.ru/wi/article_10750.html

17. Semyachkin A.A. Rossiisko-indiiskaya kontseptsiya strategicheskogo partnerstva // Mezhdunarodnye otnosheniya.2013.-2.-C. 118-122. DOI: 10.7256/2305-560X.2013.02.2.

18. I. V. Surma, V. I. Anikin Sovremennaya Rossiya: metodologicheskie aspekty strategii politicheskogo i ekonomicheskogo razvitiya // Natsional'naya bezopasnost' / nota bene.-2012.-3.-C. 4-16.

19. Smirnov A.M. Rossiya i NATO v sisteme evropeiskoi bezopasnosti // Natsional'naya bezopasnost' / nota bene.-2013.-5.-C. 12-25. DOI: 10.7256/2073-8560.2013.5.9748.

20. Sulakshin S.S. Chelovek i gosudarstvo: razvitie i upravlenie. Sbornik trudov. T. 1 - M.: Nauchnyi ekspert, $2013 .-600$ c.

21. Aleinikov A.V. Sistemnye konflikty v Rossii: kontseptual'nye osnovaniya analiza. Stat'ya 1. // NB: Problemy obshchestva i politiki. 2013. - 7. - C. 94 - 140. DOI: 10.7256/2306-0158.2013.7.2306. URL: http://www.e-notabene.ru/pr/article_2306.html 